\title{
CYP2A6 gene polymorphisms impact to nicotine metabolism
}

\author{
Dewi Muliaty, ${ }^{1}$ Irawan Yusuf, ${ }^{2}$ Rianto Setiabudy, ${ }^{3}$ Septelia I. Wanandi ${ }^{4}$ \\ ${ }^{1}$ Postgraduate Program Faculty of Medicine, Hasanuddin University, Makassar, Indonesia \\ ${ }^{2}$ Department of Physiology Faculty of Medicine, Hasanuddin University, Makassar, Indonesia \\ ${ }^{3}$ Department of Pharmacology Faculty of Medicine, University of Indonesia, Jakarta, Indonesia \\ ${ }^{4}$ Department of Biochemistry Faculty of Medicine, University of Indonesia, Jakarta, Indonesia
}

\begin{abstract}
Abstrak
Nikotin adalah senyawa utama di dalam tembakau yang menimbulkan ketergantungan pada rokok. Nikotin diinaktivasi oleh tubuh menjadi kotinin melalui kerja enzim CYP2A6. Polimorfisme genetik CYP2A6 memegang peranan penting pada kebiasaan merokok dan ketergantungan pada nikotin. Telah diketahui terdapat alel gen CYP $2 A 6^{*} 1 A$ (wild type) yang berhubungan dengan metabolisme nikotin normal/cepat, dan beberapa variasi genetik seperti alel CYP $2 A 6 * 4, C Y P 2 A 6^{* 7}$, CYP2A6*9, CYP $2 A 6^{*} 10$, yang berkaitan dengan penurunan aktivitas metabolisme nikotin. Variasi aktivitas metabolisme nikotin ini berpengaruh pada kadar nikotin plasma. Perokok memerlukan kadar nikotin tertentu pada otaknya, sehingga pada individu dengan metabolisme nikotin yang cepat diperlukan jumlah rokok yang lebih banyak. Sebaliknya, pada individu dengan metabolisme nikotin yang lambat, nikotin plasma lambat diinaktivasi dan akan mengakibatkan gejala toksik, sehingga ketergantungan pada rokok menjadi lebih rendah. (Med J Indones 2010; 19:46-51)
\end{abstract}

\begin{abstract}
Nicotine is a major addictive compound in tobacco cigarette smoke. After being absorbed by the lung nicotine is rapidly metabolized and mainly inactivated to cotinine by hepatic cytochrome P450 2A6 (CYP2A6) enzyme. Genetic polymorphisms in CYP2A6 may play a role in smoking behavior and nicotine dependence. CYP2A6*1A is the wild type of the CYP2A6 gene which is associated with normal or extensive nicotine metabolism. In the CYP2A6 gene, several polymorphic alleles have been reported such as CYP2A6*4, CYP2A6*7, CYP2A6*9, and CYP2A6*10 which are related to decreasing nicotine metabolism activity. The variation of nicotine metabolism activity could alter nicotine plasma levels. Smokers need a certain level of nicotine in their brain and must smoke regularly because of nicotine's short half-life; this increases the number of smoked cigarettes in extensive metabolizers. Meanwhile, in slow metabolizers, nicotine plasma level may increase and results in nicotine toxicity. This will eventually lower the risk of dependence. (Med J Indones 2010; 19:46-51)
\end{abstract}

Key words: cotinine, hepatic cytochrome P450 2A6, smoking behavior

Cigarette smoking is one of the main public health concerns. Approximately 1.2 billion people worldwide are known to smoke tobacco daily, resulting in the global consumption rate of 5.6 trillion cigarettes per year at the end of the $20^{\text {th }}$ century. An estimated 4.2 million people die annually from tobacco-related diseases. Reports have shown that stopping smoking can substantially reduce mortality risk. Approximately $35 \%$ of smokers attempt to quit each year, but fewer than $5 \%$ are successful without therapy. ${ }^{1}$ There is a wide variation in nicotine metabolism among individuals, and this fact results in a wide variation in nicotine plasma concentration when standard pharmacological therapy doses are taken.

Recent researches provided evidence that smoking habits are influenced not only by environmental but also genetic factors. The involved genes in the metabolism of nicotine are biologically plausible for studies of

Correspondence email to: dewiliusvia@prodia.co.id smoking behavior. Individuals with particular genetic predispositions and those who are exposed to certain environmental conditions may be at greater risk for dependency on nicotine.

In humans, the hepatic enzyme cytochrome P450 2A6 (CYP2A6) accounts for the majority of the metabolic inactivation of nicotine to cotinine. ${ }^{1-3}$ At present 49 variant alleles have been identified for the CYP2A6 gene. The genotype of CYP2A6 among races has been studied. Recent findings have increased the knowledge concerning ethnic differences in the CYP2A6 variant allele frequencies. Several variant alleles have been reported to decrease or delete the enzymatic activity. ${ }^{4}$ In this review, the relationship between the interindividual variability in nicotine metabolism and genetic polymorphism of the CYP2A6 in some ethnics, and the implication of the CYP2A6 polymorphisms in smoking behavior are discussed. 


\section{THE RELATIONSHIP OF CYP2A6 GENETIC POLYMORPHISM AND NICOTINE METABOLISM}

Smoking a cigarette delivers nicotine rapidly to the pulmonary vein blood, from which it moves quickly to the left ventricle of the heart, to the systemic arterial circulation, and finally to the brain. The lag time between a cigarette puff and nicotine reaching the brain is 10 to 20 seconds. The short time interval between puffing and nicotine entering the brain also allows the smoker to titrate the dose of nicotine to a desired pharmacological effect, further reinforcing drug selfadministration and facilitating the development of addiction. Nicotine binds to brain tissues with high affinity, and the receptor binding capacity is higher in smokers compared with nonsmokers. The increase in the binding is due to a higher number of nicotinic cholinergic receptors in the brain of the smokers. ${ }^{5}$

The plasma half-life of nicotine after intravenous infusion or cigarette smoking is about 2 hours in average. The increment in venous blood nicotine concentration after smoking a single cigarette ranges from 5 to 30 $\mathrm{ng} / \mathrm{mL}$, depending on how a cigarette is smoked. In a recent study, the mean nicotine boost after smoking a cigarette was $10.9 \mathrm{ng} / \mathrm{ml}$ in smokers without smoking abstinence. ${ }^{6}$ Blood nicotine level reaches the peak at the end of smoking a cigarette, and decline rapidly over the next 20 minutes due to tissue distribution. The distribution half-life averages about 8 minutes. Nicotine will be eliminated from the blood in 1-2 hours.

\section{Nicotine metabolism}

Approximately $70 \%$ to $80 \%$ of nicotine is metabolized into cotinine, and $90 \%$ of this conversion is mediated by CYP2A6 enzyme. Cotinine is subsequently oxidized to trans-3-hydroxycotinine. ${ }^{5,7,8}$ Cotinine is present in the blood of smokers in much higher concentration than nicotine. Cotinine blood concentration is about 250 to $300 \mathrm{ng} / \mathrm{mL}$ in groups of cigarette smokers. After stopping smoking, cotinine level declines in a log linear model with a half-life of about $16-18$ hours. ${ }^{5,7}$ Because of the long half-life, cotinine has been used as a biomarker for daily intake, both in cigarette smokers and in whom exposed to environmental tobacco smoke. Nakajima et al calculated the cotinine/nicotine ratio of the plasma as an index of nicotine metabolism. ${ }^{9}$

Substantial variation in CYP2A6 protein level and activity exists, and in vivo studies on nicotine metabolism indicate large inter-individual variation in CYP2A6 activity. These differences are associated with genetic polymorphisms of the CYP2A6 gene. ${ }^{10}$

\section{Polymorphisms of the CYP2A6 gene and their impact}

There are more than 20 variant alleles that have been characterized for the CYP2A6 gene (Table 1). The wild type of the CYP2A6 gene is CYP2A6*1A. There are genetic polymorphisms in human CYP2A6 gene, and several mutant alleles have been reported to decrease or abolish the enzyme activity. ${ }^{8}$ The CYP2A6*1B allele has a gene conversion with CYP2A7 in the $3^{\text {'- }}$ untranslated region. ${ }^{11}$ The CYP2A6*3 allele has gene conversions with CYP2A7 in exons 3, 6, and 8, ${ }^{12,13}$ and CYP2A7 is catalytically inactive.

CYP2A6*4 is a whole gene deleted allele, which is completely lack of the enzyme activity. ${ }^{14-16}$ Some Alleles possess a single nucleotide polymorphism (SNP), such as CYP2A $6 * 2, \mathrm{CYP} 2 \mathrm{~A} 6 * 5, \mathrm{CYP} 2 \mathrm{~A} 6 * 6, \mathrm{CYP} 2 \mathrm{~A} 6 * 7$, and CYP2A6*9 (T-48G in TATA box). ${ }^{3}$ CYP2A6*10 allele which has two simultaneous amino acid substitutions of CYP2A6*7 and CYP2A6*8, ${ }^{17-18}$ and CYP2A6*11 $(\mathrm{S} 224 \mathrm{P})^{19}$ have been reported to have a decrease in enzyme activity. Oscarson et al. reported a novel CYP2A7/CYP2A6 hybrid allele (CYP2A6*12) that carries an unequal crossover in intron $2 .{ }^{20}$ Kiyotani et al. reported additional alleles that possess a single amino acid substitution i.e. CYP2A6*13, CYP2A6*14, CYP2A6*15, and CYP2A6*16. ${ }^{21}$ Nakajima et al evaluated CYP2A $6 * 17$, CYP2A6*18, CYP2A6*19, and CYP2A6*20 alleles. The CYP2A6*17 and CYP2A6*19 alleles have decreased enzyme activity, and the CYP2A6*20 allele produces a truncated protein with no acvity, ${ }^{22}$ (Table 1 ). The sequence alignments of the CYP2A6 gene and its polymorphism is shown in figure 1. 
A.

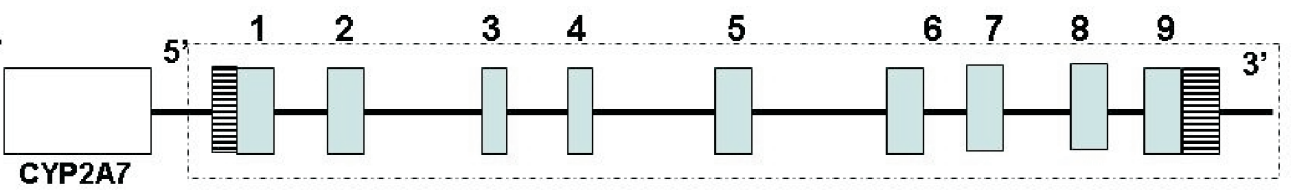

B.

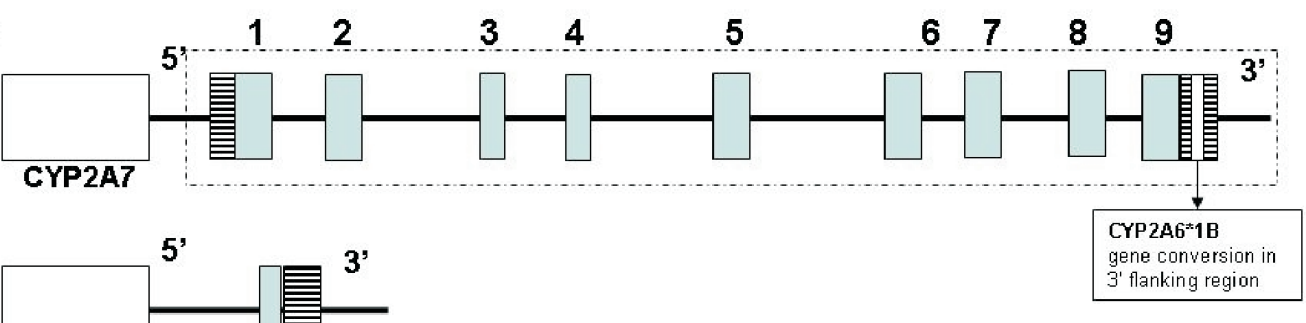

c.

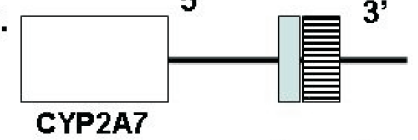

D. 12

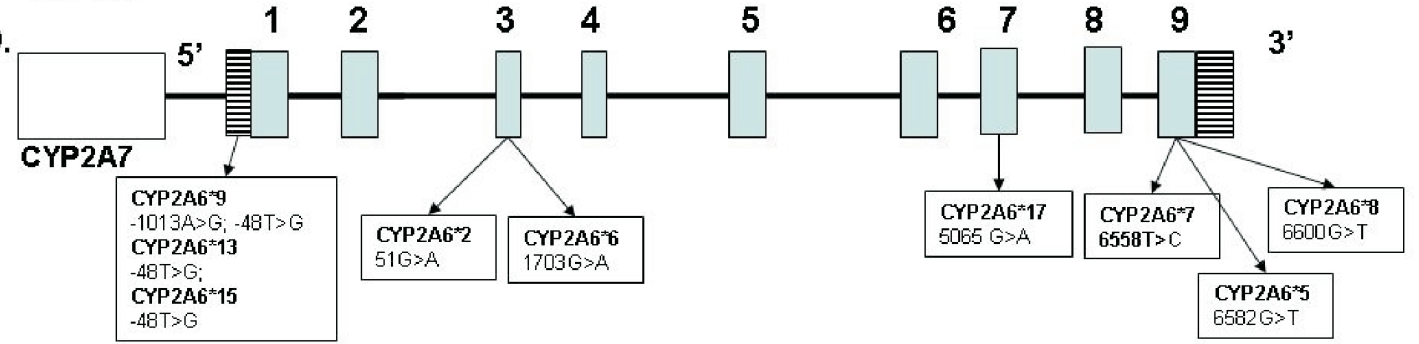

Intron of CYP2A6 gene

Entranslated region

CYP2A7 gene

Figure 1. Sequence alignments of the CYP2A6 gene and the polymorphisms

A. Wild type gene of the CYP2A6 (CYP2A6*1A)

B. Gene conversion with CYP2A7 in 3' untranslated region of CYP2A6 (CYP2A6*1B)

C. CYP2A6 whole gene deletion (CYP2A6*4)

D. Single nucleotide polymorphism (SNP) of the CYP2A6 gene

Yamanaka et al found that in Japanese and koreans, cotinine formation was impaired in individuals with homozygotes of either CYP2A6*4, CYP2A6*7 or CYP2A6*10 alleles. In particular, cotinine was not detectable in plasma 2 hours after nicotine intake in individuals who had the CYP2A6*4/CYP2A6*4 genotype. In addition, the CYP2A $6 * 9$ allele causes a decrease in nicotine metabolism. ${ }^{8}$ In Caucasians, it was reported that homozygotes of the CYP2A $6 * 2$ allele were deficient in nicotine metabolism. ${ }^{23}$ The genotype frequencies of CYP2A6 are highly variable among races. The frequencies of CYP2A $6 * 4, * 7$ and $* 9$ alleles are higher in Chinese $(7 \%, 3 \%, 16 \%$, respectively), Japanese $(17 \%, 11 \%, 20 \%)$, and Koreans $(11 \%, 4 \%$, $22 \%$ ). This is in contrast to 1 and $0 \%$ for alleles $* 4$ and $* 7$, in Caucasians. However, the frequency of $* 9$ is high in Swedish (5\%) and Turkish (7\%) populations, ${ }^{2}$ while CYP2A6*2 and CYP2A6*12 alleles appeared in Caucasian ( $3 \%$ and $2 \%$ respectively). ${ }^{7}$ Nurfadhlina et al. reported the frequency for CYP2A6*4 was 7\% among Malays, 5\% among Chinese, and 2\% among Indians. ${ }^{24}$ The CYP2A6 alleles and their polymorphism effect to enzyme activity is summarized in Table 1. 
Table 1. CYP2A6 alleles and their polymorphism effect to enzyme activity

\begin{tabular}{|c|c|c|c|}
\hline Allele name & Type of polymorphism & Enzyme activity & Reference number \\
\hline CYP2A6*1A & Wild Type & Normal & 8 \\
\hline CYP2A6*1B & $\begin{array}{l}\text { Gene conversion with CYP2A7 in 3'- UTR } \\
\text { (flanking region) }\end{array}$ & Increase & 11 \\
\hline CYP2A6*2 & $\mathrm{L} 160 \mathrm{H}$ & None & $7,17,18,23$ \\
\hline CYP2A6*3 & CYP2A6 / CYP2A7 hybrid & $?$ & 12,13 \\
\hline CYP2A6*4 & CYP2A6 allele gene deleted & None & $2,8,14,15,16,24$ \\
\hline CYP2A6*5 & G479V & None & 17,18 \\
\hline CYP2A6*6 & R128Q & Decrease & 17,18 \\
\hline CYP2A6*7 & $\mathrm{I} 471 \mathrm{~T}$ & Decrease & $2,8,17,18$ \\
\hline CYP2A6*8 & $\mathrm{R} 485 \mathrm{~L}$ & $?$ & 17,18 \\
\hline CYP2A6*9 & $-1013 \mathrm{~A}>\mathrm{G} ;-48 \mathrm{~T}>\mathrm{G}$ & Dccrease & $2,8,17,18$ \\
\hline CYP $2 \mathrm{~A} 6 * 10$ & I471T; R485L & Dccrease & $8,17,18$ \\
\hline CYP2A6*11 & $\mathrm{S} 224 \mathrm{P}$ & Dccrease & 19 \\
\hline CYP2A6*12 & $\begin{array}{l}10 \text { amino acid substitutions CYP2A7 / } \\
\text { CYP2A6 hybrid }\end{array}$ & Decrease & 7,20 \\
\hline CYP2A6*13 & $-48 \mathrm{~T}>\mathrm{G} ; \mathrm{G} 5 \mathrm{R}$ & $?$ & 21 \\
\hline CYP2A6*14 & S29N & $?$ & 21 \\
\hline CYP2A6*15 & $-48 \mathrm{~T}>\mathrm{G} ; \mathrm{K} 194 \mathrm{E}$ & $?$ & 21 \\
\hline CYP2A6*16 & $\mathrm{R} 203 \mathrm{~S}$ & $?$ & 21 \\
\hline CYP2A6*17 & $\mathrm{V} 365 \mathrm{M}$ & Decrease & 22 \\
\hline CYP2A6*18 & Y392F & Decrease & 22 \\
\hline CYP2A6*19 & Y392F; 1471T & Decrease & 22 \\
\hline CYP2A6*20 & Frameshift & None & 22 \\
\hline
\end{tabular}




\section{IMPLICATION OF CYP2A6 GENETIC POLYMORPHISM IN SMOKING BEHAVIOR}

Smokers adapt their smoking behavior to maintain their plasma nicotine concentration. The urge of smoking may be partly affected by differing rates of nicotine metabolism, and genetic variation in CYP2A6 as the main nicotine-inactivating enzyme that has been the focus of many studies. ${ }^{7}$ There is a relationship between genetic polymorphism of the CYP2A6 gene and interindividual differences in nicotine metabolism into cotinine. ${ }^{9,20,25,26}$ The phenotyping of nicotine metabolism was performed by measuring the metabolic index of nicotine by looking at the cotinine/ nicotine ratio in plasma 2 hours after chewing one piece of nicotine gum. Cotinine was not detected in plasma 2 hours after nicotine intake in individuals who were genotyped as CYP2A6*4/CYP2A6*4. ${ }^{8,9}$ CYP2A6 genetic polymorphisms associated with decreased nicotine metabolism (e.g. CYP2A6*2, CYP2A6*4) have been associated with a decreased risk for smoking, lower cigarette consumption, shorter duration of smoking, and increased ability to quit. ${ }^{27}$ Variability in the rates of nicotine metabolism may alter nicotine plasma levels. Individuals with at least one inactive allele (CYP2A6*2 or CYP2A6*4), would smoke fewer cigarettes and less often to experience withdrawal symptoms compared with normal inactivator (CYP2A6*1). ${ }^{7}$ Smokers homozygous for wild type CYP2A6 alleles (CYP2A6*1a) smoked significantly more cigarettes per day than heterozygous smokers (carrier of one defective CYP2A6 allele). ${ }^{28}$ Recent studies suggest that several aspects of smoking are influenced by CYP2A6 genetic variation. More specifically, these effects appear to vary with the point in smoking history and are influenced by factors such as status of nicotine dependence and duration of smoking. Malaiyandi et al. suggested that during adolescence, a slow inactivator genotype increases the risk for nicotine dependence, while still reducing the amount of smoked cigerette. If these dependent smokers became adults and more regular smoking occured, it appears that slow nicotine inactivators smoke less and for shorter duration compared with normal nicotine inactivators. CYP2A6-mediated slow nicotine inactivation may alter tolerance and withdrawal, such that these individuals are able to quit sooner. ${ }^{?}$

The inter-individual and ethnic variations in nicotine metabolism due to genetic polymorphisms of the CYP2A6 gene in Caucasian, Chinese, Korean, and Japanese subjects have been known. However, the allele frequencies ofCYP2A6variant in Indonesian population are still unknown. Therefore, the associations between the CYP2A6 polymorphisms, nicotine metabolism, and smoking behavior in Indonesian also have not been cleared.

The impact of CYP2A6 polymorphisms on smoking behavior and nicotine dependency requires further investigation, especially for Indonesian populations which has not been studied. The potential temporal effect of CYP2A6 genetic variation emphasizes the importance of understanding the various factors modulating the vulnerability to nicotine dependence and the need to identify more specific smoking and disease prevention strategies.

\section{REFERENCES}

1. Sellers EM, Tyndale RF, Fernandes LC, Decreasing smoking behaviour and risk through CYP2A6 inhibition. DDT. 2003; 8:487-93.

2. Minematsu N, Nakamura H, Furuuchi $M$, Nakajima $\mathrm{T}$, Takahashi S, Tateno $\mathrm{H}$ et al. Limitation of cigarette consumption by CYP2A6*4, *7 and *9 polymorphisms. Eur Respir J. 2006; 27: 289-92.

3. O'Loughin J, Paradis G, Kim W, DiFranza JR, Meshefedijan G, McMillan E, et al. Genetically decreased CYP2A6 and the risk of tobacco dependence: a prospective study in novice smokers. Tob Control. 2004;13:422-8.

4. Nakajima M. Smoking behavior and related cancers: The role of CYP2A6 polymorphisms. Current Opinion in Molecular Therapeutics. 2007;9:538-44.

5. Hukkanen J, Jacob P, Benowitz NL. Metabolism and Disposition Kinetics of Nicotine. Pharmacol Rev. 2005;57:79-115.

6. Patterson F, Benowitz N, Shields P, Kaufmann V, Jepson C, Wileyto $\mathrm{P}$, et al. Individual differences in nicotine intake per cigarette. Cancer Epidemiol Biomarkers Prev. 2003;12: 468-71.

7. Malaiyandi V, Sellers EM, Tyndale RF. Implications of CYP2A6 genetic variation for smoking behaviors and nicotine dependence. Clin Pharmacol Ther. 2005;77:145-58.

8. Yamanaka H, Nakajima M, Nishimura K, Yoshida R, Fukami T, Katoh M, et al. Metabolic profile of nicotine in subjects whose CYP2A6 gene is deleted. Europ J Pharmaceut Sc. 2004; 22:419-42.

9. Nakajima M, Kwon JT, Tanaka N, Zenta T, Yamamoto Y, Yamamoto $\mathrm{H}$, et al. Relationship between interindividual differences in nicotine metabolism and CYP2A6 genetic polymorphism in humans. Clin Pharmacol Ther. 2001;68:72-8.

10. Benowitz NL, Jacob P III. Trans-3'-hydroxycotinine: disposition kinetics, effects and plasma levels during cigarette smoking. Br J Clin Pharmacol. 2001;51:53-9.

11. Oscarson M, McLellan RA, GullsteÂn H, AguÂndez $\mathrm{JAG}$, BenõÂtez J, Rautio A, et al. Identification and 
characterization of novel polymorphisms in the CYP2A locus: implications for nicotine metabolism. FEBS Lett. 1999a; 460:321-7.

12. Fernandez-Salguero $\mathrm{P}$, Hoffman SMG, Cholerton S, Mohrenweiser H, Raunio H, Rautio $\mathrm{T}$, et al. A genetic polymorphism in coumarin 7-hydroxylation: sequence of the human CYP2A genes and identi ${ }^{\circledR}$ cation of variant CYP2A6 alleles. Am J Hum Genet. 1995; 57:651-60.

13. Nakajima M, Yoshida R, Fukami T, McLeod HL, Yokoi T. Novel human CYP2A6 alleles confound gene deletion analysis. FEBS Lett. 2004;569:75-81.

14. Oscarson M, McLellan RA, GullsteÂn H, Yue Q-Y, Lang MA, Bernal ML, et al. Characterization and PCR-based detection of a CYP2A6 gene deletion found at a high frequency in a Chinese population. FEBS Lett. 1999b; 448:105-10.

15. Ariyoshi N, Takahashi Y, Miyamoto M, Umetsu Y, Daigo S, Tateishi T, et al. Structural characterization of a new variant of the CYP2A6 gene (CYP2A6*1B) apparently diagnosed as heterozygotes of CYP2A6*1A and CYP2A6*4C. Pharmacogenetics. 2000;10:687-93.

16. Ariyoshi N, Miyamoto M, Umetsu Y, Kunitoh H, DosakaAkita H, Sawamura Y, et al. Genetic polymorphism of CYP2A6 gene and tobacco-induced lung cancer risk in male smokers. Cancer Epidemiol Biomarkers Prev. 2002;11:890-4.

17. Yoshida R, Nakajima M, Watanabe Y, Kwon JT, Yokoi T. Genetic polymorphisms in human CYP2A6 gene causing impaired nicotine metabolism. Br J Clin Pharmacol. 2002; 54:511-7.

18. Xu C, Rao YS, Xu B, Hoffmann E, Jones J, Sellers EM, et al. An in vivo pilot study characterizing the new CYP2A6*7, *8, and *10 alleles. Biochem Biophys Res Commun. 2002; 290: 318-24.

19. Daigo S, Takahashi Y, Fujieda M, Ariyoshi N,Yamazaki H, Koizumi W, et al. A novel mutant allele of the CYP2A6 gene (CYP2A6*11) found in a cancer patient who showed poor metabolic phenotype towards tegafur. Pharmacogenetics. 2002;12: 299-306.

20. Oscarson M, McLellan RA, Asp V, Ledesma M, Ruiz ML, Sinues B, et al. Characterization of a novel CYP2A7/ CYP2A6 hybrid allele (CYP2A6*12) that causes reduced CYP2A6 activity. Hum Mutat. 2002;20:275-83.

21. Kiyotani K, Fujieda M, Yamazaki H, Shimada T, Guengerich FP, Parkinson A, et al. Twenty one novel single nucleotide polymorphisms (SNPs) of the CYP2A6 gene in Japanese and Caucasians. Drug Metab Pharmacokinet. 2002;17:482-7.

22. Nakajima M, Fukami T, Yamanaka H, Higashi E, Sakai H, Yoshida R, et al. Comprehensive evaluation of variability in nicotine metabolism and CYP2A6 polymorphic alleles in four ethnic populations. Clin Pharmacol Ther. 2006;80:282-97.

23. Nakajima M, Yoshida R, Fukami T, McLeod HL, Yokoi T. Novel human CYP2A6 alleles confound gene deletion analysis. FEBS Lett. 2004;569:75-81.

24. Nurfadhlina M, Foong K, The LK, Tan SC, Mohd Zaki S, Ismail R. CYP2A6 polymorphisms in Malays, Chinese, Indians. Xenobiotica. 2006;36:684-92.

25. Kwon JT, Nakajima M, Chai S, Yom YK, Kim HK, Yamazaki $\mathrm{H}$, et al. Nicotine metabolism and CYP2A6 allele frequencies in Koreans. Pharmacogenetics. 2001;11:317-23.

26. Yoshida R, Nakajima M, Nishimura K, Tokudome S, Kwon JT, Yokoi T. Effects of polymorphism in promoter region of human CYP2A6 gene (CYP2A6*9) on expression level of messenger ribonucleic acid and enzymatic activity in vivo and in vitro. Clin Pharmacol Ther. 2003;74:69-76.

27. Schoedel K, Hoffmann E, Rao Y, Sellers E, Tyndale RF. Ethnic variation in $C Y P 2 A 6$ and association of genetically slow nicotine metabolism and smoking in adult Caucasians. Pharmacogenetics. 2004;14:615-26.

28. Ahijevych $\mathrm{K}$. Nicotine metabolism variability and nicotine addiction in nicotine conference summary 2006. The National Institute on Drug Abuse (NIDA), National Institutes of Health (NIH), U.S. Department of Health and Human Services. 